\title{
Kinetic Mechanism of Desilicated Fly Ash Lime Consumption
}

\author{
Thabo FALAYI ${ }^{1}$, Felix Ndubisi OKONTA ${ }^{1 *}$, Freeman NTULI $^{2}$ \\ ${ }^{1}$ Department of Civil Engineering Sciences, University of Johannesburg, P.O. Box 524, Auckland Park 2006, \\ Johannesburg, South Africa \\ ${ }^{2}$ Department of Chemical Engineering, University of Johannesburg, P.O. Box 17011, Doornfontein 2028, Johannesburg, \\ South Africa \\ crossref http://dx.doi.org/10.XXXX/j01.xxxxxxx
}

Received 29 February 2016; accepted 10 June 2016

\begin{abstract}
This paper presents study of the kinetic mechanism of lime consumption using desilicated fly ash (DFA). Desilicated fly ash (DFA) a residue from leaching of silica from fly ash was stabilised using lime at elevated temperatures. DFA and lime were mixed in different ratios at optimum moisture content and maximum dry density and then cured at $40{ }^{\circ} \mathrm{C}$, $80^{\circ} \mathrm{C}$ and $100^{\circ} \mathrm{C}$ for 4 days. $80^{\circ} \mathrm{C}$ was found to be the optimum curing temperature. The DFA: lime ratio of $70: 30$ was found to have an average UCS of 8.6 MPa. Lime consumption was found to follow modified Jander kinetics with activation energy of $16 \mathrm{~kJ} / \mathrm{mol}$ and a reaction grade of 3 meaning that the reaction was controlled by diffusion of reactants through a dense layer of reaction products. The main hydration products were calcium silicate hydrate and tricalcium aluminate. Toxicity leaching tests showed a $79 \%$ reduction in the leachability of trace and heavy metals. Therefore, DFA can successfully be stabilised using lime.

Keywords: desilicated fly ash, modified Jander kinetics, toxicity.
\end{abstract}

\section{INTRODUCTION}

Fly ash (FA) is the micro spherical particulate waste gathered from flue gases during coal combustion for electricity generation. South Africa uses low grade coal for power generation, which results in approximately $25 \%$ or greater inorganic residue, remaining as waste. The major component of this waste is FA [1]. Metal or mineral recovery from FA is one of the numerous ways to use FA as a resource. Elements such as titanium, germanium, silica, aluminium, cadmium, calcium and magnesium [2-4] have been recovered from FA. Silica recovery from FA has led to the synthesis of zeolites, nanosilica particles and xerogels for use as adsorbents [5,6]. The residue (desilicated fly ash (DFA)) from silica extraction from FA has not received attention in research. Lime stabilisation of the desilcated fly ash is one of the alternative ways to make valuable civil engineering materials from DFA since lime has been used to stabilise high alumina low silica FA [7]. The kinetic mechanism of lime stabilisation of DFA needs therefore to be studied so that the mechanism is understood so as to make quality civil engineering materials. There are varying kinetic mechanism reported in literature by various researchers to explain lime consumption in FA and lime composites. These include pseudo first order $[8,9]$ and pseudo second order [10] modified second order [9]. The above kinetics and thermodynamic studies do not take into account the amount of FA used in hydration reaction. A quick survey on lime and FA hydration reaction shows that less than $40 \%$ FA takes part in hydration reaction [11-13].

This necessitates the need for research in lime and DFA reactions where the amount of DFA that partakes in

\footnotetext{
${ }^{*}$ Corresponding author. Tel.: +275592342 ;

E-mail address: fnokonta@uj.ac.za (F.N.Okonta)
}

the hydration reactions is accounted for in calculating thermodynamic and kinetic parameters. The influence of curing temperature and time on lime consumption by DFA were investigated in detail. In addition, series of tests on toxicity leachability using Toxicity Characteristic Leaching Procedure (TCLP) were conducted in to assess the in service pollution potential of the DFA composite.

\section{EXPERIMENTAL METHODS}

Oven dry DFA and lime were dry mixed at ratios of 90:10, 80:20, 70:30 and 60:40. Table 1 shows the X-ray Fluorescence (XRF) characterisation of DFA. The $\mathrm{pH}$ of DFA was found to be 12.28 . The $\mathrm{pH}$ was higher than that typical FA because DFA has more basic oxides (especially $\mathrm{K}_{2} \mathrm{O}$ ) than FA which then contribute to the high alkalinity. DFA was also characterised by low silica content due to leaching of silica.

Water was then quantitatively added at the optimum moisture content (OMC) of each mix. The DFA-lime water mixture was then mixed thoroughly to uniformly spread the moisture amongst the dry solids. The calculated weight of water added was done after lime had slaked. For each mix ratio at a particular water content, three moulds were prepared. The mixed DFA-lime - water mixture was then cast into a $100 \times 100 \times 100 \mathrm{~mm}^{3}$ mould and pressure molded from one end using a moulding load of $5 \mathrm{kN}$. The moulding was done at maximum dry densities for each particular ratio of DFA: lime. When the mould had obtained sufficient strength, it was demoulded and subsequently sealed in a plastic. Casts which showed uneven surfaces due to demoulding or pressure casting were rejected. The above procedure was repeated with as received FA for comparison. The casts were then cured for $96 \mathrm{~h}$ at $80^{\circ} \mathrm{C}$. After $96 \mathrm{~h}$ the cast were removed from the oven and allowed to cool to room temperature. 
Unconfined Compressive Strength (UCS) was determined in accordance with ASTM D2166. Free lime content was determined using the method proposed by Rao and Asha (2012) [8]. A standard solution of ammonium acetate was prepared by dissolving $1.6 \mathrm{~g}$ of ammonium acetate in $100 \mathrm{~mL}$ of ethanol using a $100 \mathrm{ml}$ volumetric flask. $0.2 \mathrm{ml}$ of phenolphthalein solution was added per every $100 \mathrm{ml}$ of ethanol glycerol solvent (2:1). $1 \mathrm{~g}$ of finely ground composite sample was added to $60 \mathrm{ml}$ of the ethanol-glycerol in a $250 \mathrm{ml}$ round bottom flask to which $2 \mathrm{~g}$ of anhydrous strontium nitrate was added. The round bottom flask was then connected to a condenser and the mixture was brought to boil for $20 \mathrm{~min}$. After $20 \mathrm{~min}$ boiling was stopped followed by filtration of the hot mixture. The filtrate was brought to boiling point and immediately titrated against the standard ammonium acetate solution to a colourless end point.

The percent free lime is calculated a:

$\%$ free $C H=E V \times 100$,

where $E$ is the lime equivalent of the ammonium acetate solution $(\mathrm{g} / \mathrm{mL})$ and $V=$ milliliters of ammonium acetate titre. An average of three casts within $10 \%$ of each other was reported as the final result.

A modified picric acid methanol method was used [11] to determine reacted/hydrated DFA. $1 \mathrm{~g}$ of DFA: lime composite was accurately weighed into a teflon beaker. A picric acid-methanol solution $(9 \mathrm{~g}: 60 \mathrm{ml})$ was added to the composite material. The mixture was stirred for $15 \mathrm{~min}$ and then subsequently $40 \mathrm{ml}$ of deionised water was added and stirring was continued for another $45 \mathrm{~min}$. The mixture was immediately filtered using ashless filter paper. The ash-less filter paper and the residue were washed with methanol until the filtrate appeared colourless and then they were further washed with $300 \mathrm{ml}$ of deionized water at $60{ }^{\circ} \mathrm{C}$. The residue and ash-less filter paper were ignited in an electric furnace at $950{ }^{\circ} \mathrm{C}$ for $60 \mathrm{~min}$. The $\%$ reacted DFA was calculated using:

$Y=\left(1-\left(S / P_{f} F\right)\right) * 100$

where $S$ is the residue per gram of the composite, $P_{f}$ is the $\%$ DFA in the composite, $F$ is the residue for pure DFA.

Table 1. XRF analysis of FA and DFA

\begin{tabular}{|c|c|c|}
\hline Parameter & FA, \% m/m & DFA, \% m/m \\
\hline $\mathrm{Na}_{2} \mathrm{O}$ & 0.0658 & 0.0658 \\
\hline $\mathrm{MgO}$ & 0.585 & 0.485 \\
\hline $\mathrm{Al}_{2} \mathrm{O}_{3}$ & 23.8 & 38.7 \\
\hline $\mathrm{SiO}_{2}$ & 45.06 & 19.6 \\
\hline $\mathrm{P}_{2} \mathrm{O}_{5}$ & 0.63 & 0.84 \\
\hline $\mathrm{SO}_{3}$ & 1.250 & 0.613 \\
\hline $\mathrm{K}_{2} \mathrm{O}$ & 1.2 & 25.2 \\
\hline $\mathrm{CaO}$ & 6.82 & 4.25 \\
\hline $\mathrm{TiO}_{2}$ & 2.54 & 2.55 \\
\hline $\mathrm{Fe}_{2} \mathrm{O}_{3}$ & 9.4 & 4.25 \\
\hline $\mathrm{LOI}$ & 7.9 & 2.5 \\
\hline$p \mathrm{pH}$ & 10.69 & 12.28 \\
\hline
\end{tabular}

\section{RESULTS AND DISCUSSION}

\subsection{Variation of UCS with DFA content}

Fig. 1 shows the variation of UCS with lime composite.

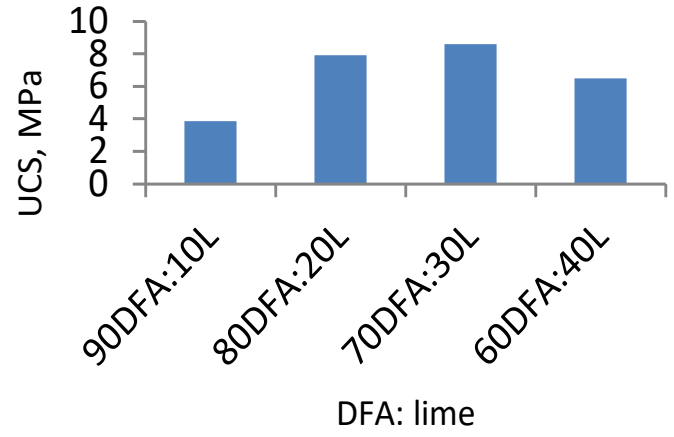

Fig. 1. Variation in UCS composites with lime content after curing at $80{ }^{\circ} \mathrm{C}$ for $96 \mathrm{~h}$

The 70:30 DFA:Lime composite had the highest UCS of $8.57 \mathrm{MPa}$. After $24 \mathrm{~h}$ of soaking in water the composite had a UCS of $6.5 \mathrm{MPa}$ and water absorption of $17.3 \%$. This composite met the minimum requirements of the ASTM C34-13 and was therefore taken for further test work.

\subsection{Effect of curing temperature}

Fig. 2 shows the variation of UCS with temperature.

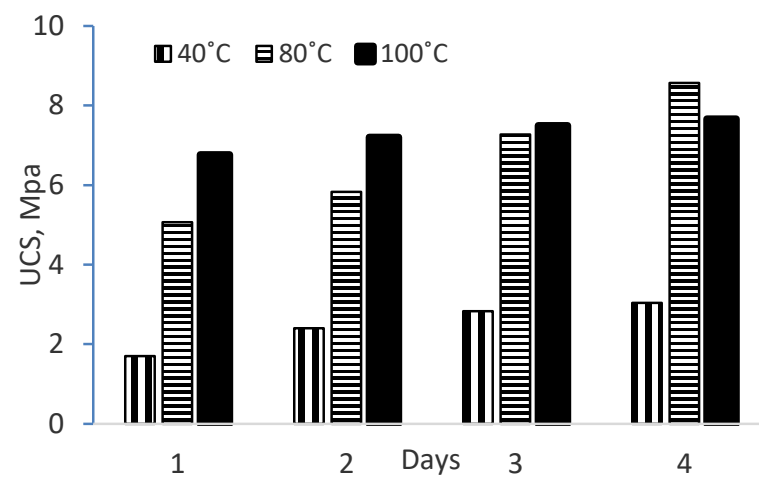

Fig. 2. Variation in UCS with curing temperature and curing time of the 70:30 DFA:lime composite

A change in temperature from $40{ }^{\circ} \mathrm{C}$ to $80{ }^{\circ} \mathrm{C}$ brought about at least $140 \%$ increase in UCS in DFA:lime composites showing that the initial temperature increase accelerated pozzolanic/hydration reaction. The increase from $80{ }^{\circ} \mathrm{C}$ to $100{ }^{\circ} \mathrm{C}$ brought about a $33 \%$ increase in UCS only after $24 \mathrm{~h}$, there after the increase in UCS was not significant with the difference at 3 days being $3 \%$. After 4 days the UCS of composites cured at $80^{\circ} \mathrm{C}$ were higher than the one at $100{ }^{\circ} \mathrm{C}$. This can be explained using SEM (Fig. 3) micrographs of the 70:30 DFA: Lime composites cured at $80{ }^{\circ} \mathrm{C}$ and $100{ }^{\circ} \mathrm{C}$.

The extensive covering of DFA particles with lime and hydration products after 1 day of curing for the composite cured at $100{ }^{\circ} \mathrm{C}$ would be the reason for the early development of high strength as compared to the one cured at $80^{\circ} \mathrm{C}$ (Fig. $3 \mathrm{a}$ and $\mathrm{b}$ respectively). The extensive covering also acts as a barrier for the further hydration of DFA particles as by the third day DFA particles were completely covered by hydration products (Fig. $3 \mathrm{c}$ ). The composite cured at $80{ }^{\circ} \mathrm{C}$ was still fairly covered by hydration products at day four allowing for further hydration to take place. 


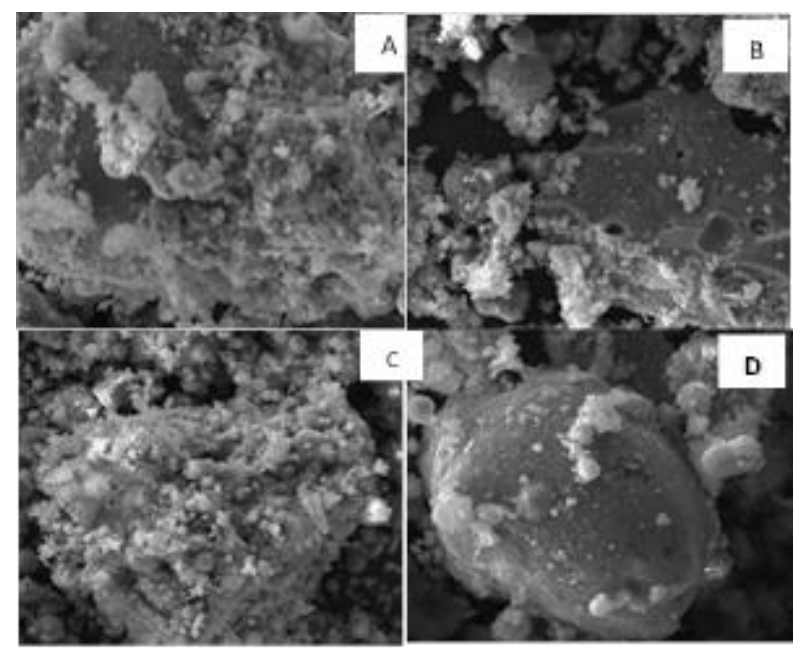

Fig. 3. SEM micrographs of 70: 30 DFA: lime composite: $\mathrm{a}-100{ }^{\circ} \mathrm{C}$ after 1 day; $\mathrm{b}-80{ }^{\circ} \mathrm{C}$ after 1 day; $\mathrm{c}-100^{\circ}$ after 3 days; $\mathrm{d}-80{ }^{\circ} \mathrm{C}$ after 4 days

\subsection{Kinetics of lime consumption}

Fig. 4 shows the variation in lime consumption with time and curing time.

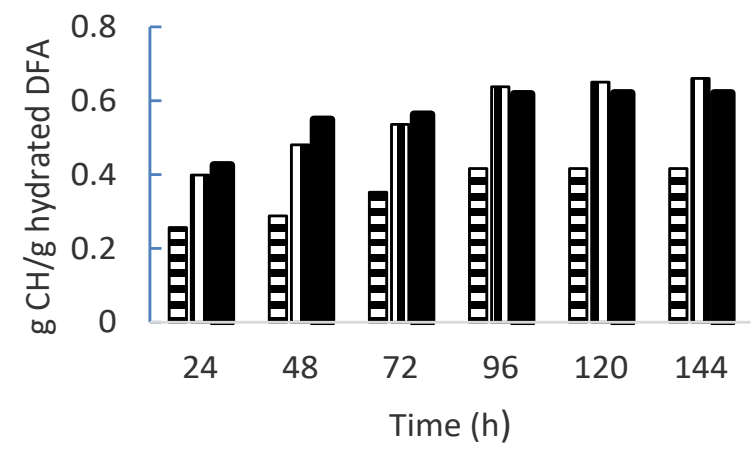

\section{$\square 40^{\circ} \mathrm{C} \quad 80^{\circ} \mathrm{C}-100^{\circ} \mathrm{C}$}

Fig. 4. Lime consumption at various temperatures over $96 \mathrm{~h}$ using DFA: Lime (70:30) composite

The highest consumption was at $100{ }^{\circ} \mathrm{C}$ up to $72 \mathrm{~h}$. The high temperature provides enough thermal energy for hydration to take place. After $24 \mathrm{~h}$ lime consumption is about 61, 69 and $69 \%$ of the $96 \mathrm{~h}$ consumption for composites cured at $40{ }^{\circ} \mathrm{C}, 80{ }^{\circ} \mathrm{C}$ and $100{ }^{\circ} \mathrm{C}$. From $96 \mathrm{~h}$ to $144 \mathrm{~h}$ the consumption of lime at $80^{\circ} \mathrm{C}$ was higher than that at $100{ }^{\circ} \mathrm{C}$. This is due to extensive encapsulation of DFA particles at $100{ }^{\circ} \mathrm{C}$ hindering further hydration (Fig. 4).

Second order kinetic model and modified Jander kinetic model were tested to see if lime consumption fitted these models. Second order was chosen because previous FA lime consumption reaction have been modelled as second order [8, 11]. Fig. 5 and Fig. 6 show the plots of the modified Jander and second order kinetics respectively.

The modified Jander plot had a better fit as it had $R^{2}$ valued greater than 0.92 . Furthermore, the $k$ values obtained from the second order plot could not be used to calculate activation energy as the Arrhenius plot had a $\mathrm{R}^{2}$ value of 0.00528 . Therefore, the modified Jander equation was chosen to describe lime consumption by DFA. One of the assumptions of the modified Jander kinetics is that for diffusion-controlled mass transfer spherical particles could be treated as flat slabs [14].

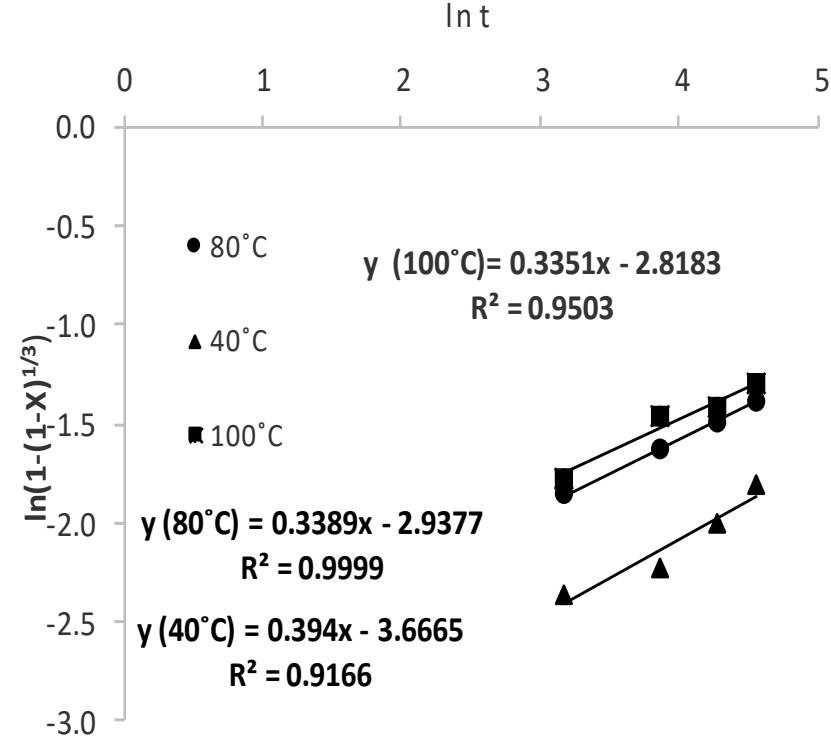

Fig. 5. Modified Jander plot at various temperatures of the 70:30 DFA:lime composite cured at $80^{\circ} \mathrm{C}$ for $96 \mathrm{~h}(X$ is the fraction of lime consumed and $t$ is temperature in Kelvin)

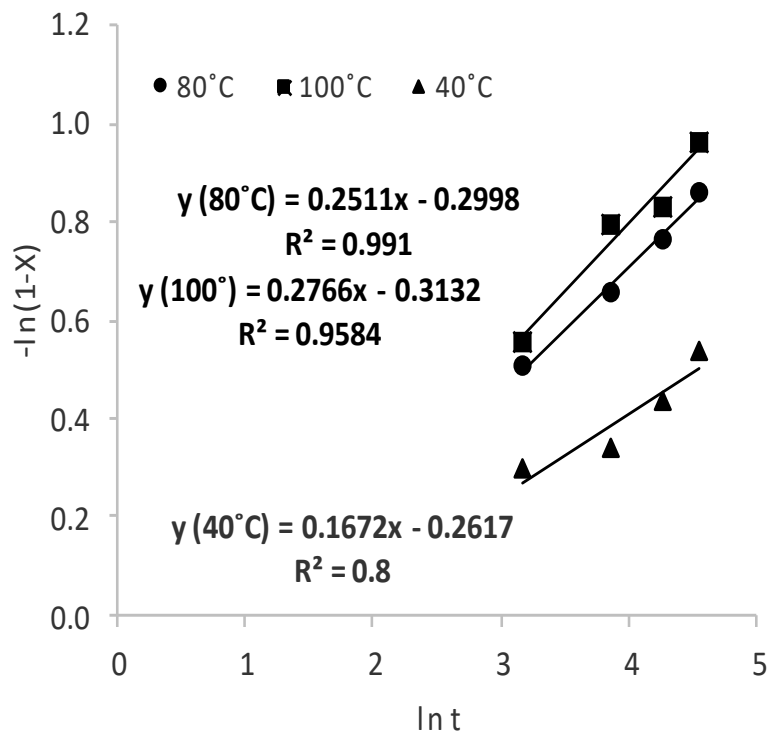

Fig. 6. Second order plot at various temperatures 70:30 DFA:lime composite cured at $80{ }^{\circ} \mathrm{C}$ for $96 \mathrm{~h}(X$ is the fraction of lime consumed and $t$ is temperature in Kelvin)

The appearance of flat slabs in the SEM micrographs (Fig. 3) further validates the validity of the use of modified Jander equation to explain the kinetics of lime consumption by DFA. The original Jander equation was modified by incorporation of the term $N$ (reaction grade) so that it can apply to broad reactions including consecutive and overlapping reactions [15]. This then suits hydration reaction of DFA since dissolution and hydration reactions are involved. The calculated $N$ values at $40{ }^{\circ} \mathrm{C}, 80^{\circ} \mathrm{C}$ and $100{ }^{\circ} \mathrm{C}$ were $2.6,3.0$ and 3.0 respectively. This therefore means that lime consumption by DFA is controlled by diffusion of reactants through a dense layer of reaction products [15]. This was also supported by the SEM micrograph analysis of DFA-lime composites (Fig. 3). The consumption of lime is greatly reduced once hydration products form around DFA particles (Fig. 3 and Fig. 4). 


\subsection{Activation energy} DFA.

Fig. 7 shows the Arrhenius plot of lime consumption using

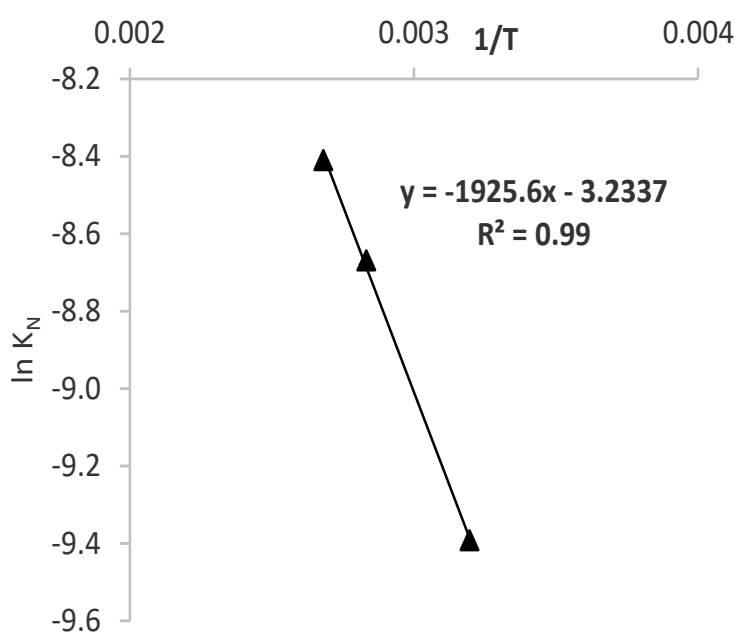

Fig. 7. Arrhenius plot of lime consumption by DFA (Where $K_{N}$ is the slope of the Modified Jander plots Fig. 5 and $T$ is the temperature in Kelvins)

The activation energy was calculated as $16 \mathrm{~kJ} / \mathrm{mol}$. Previous FA research has given figures of $47.3-63.1 \mathrm{~kJ} / \mathrm{mol}$ [9] using modified second order and $1.6-30.7 \mathrm{~kJ} / \mathrm{mol}[10]$. The major difference is that the amount of DFA that reacted or participated in hydration reaction is quantified in this research. A quick survey of literature shows that only a small quantity of FA takes part in hydration reaction (below $40 \%$ ) [11-13]. Therefore, it was imperative to include the mass of reacted hydrated DFA in calculation of reaction extent rather than the whole DFA added to the composite.

\subsection{Toxicity characteristic leaching procedure (TCLP)}

Table 2 shows the leachability of metals from the 70:30 DFA: lime composite and the 80:20 FA:lime composite. The results are an average of three samples.

Table 2. TCLP results of the 70:30 DFA:lime composite

\begin{tabular}{|c|c|c|c|}
\hline Element & DFA, ppm & 70:30 composite, $\mathrm{ppm}$ & \% reduction \\
\hline $\mathrm{Cr}$ & 0.116 & 0.028 & 75.8 \\
\hline $\mathrm{Mn}$ & 0.388 & 0.015 & 96.1 \\
\hline $\mathrm{Fe}$ & 5.98 & 1.25 & 79.1 \\
\hline $\mathrm{Ni}$ & 0.215 & 0.022 & 89.8 \\
\hline $\mathrm{Cu}$ & 0.315 & 0.035 & 88.9 \\
\hline $\mathrm{Zn}$ & 0.125 & 0.001 & 99.2 \\
\hline $\mathrm{Ba}$ & 10.3 & 0.821 & 92 \\
\hline $\mathrm{Pb}$ & 0.286 & 0.0141 & 95.1 \\
\hline
\end{tabular}

Stabilisation of DFA with lime using a ratio of 70:30 DFA: lime reduced the leachable heavy and trace metals by over $79 \%$ (Table 5). An interesting point is that no new crystalline structure was formed which incorporated the heavy and trace metals in Table 2 (Fig. 8) yet their leachability was reduced in the composite. The explanation for this is that the covering/encapsulation of DFA particles with hydration products forms a barrier thereby preventing the leaching of heavy and trace metals (Fig. 5 and Fig. 6).

\subsection{Development of hydration products}

Fig. 8 shows the hydration products of the composite

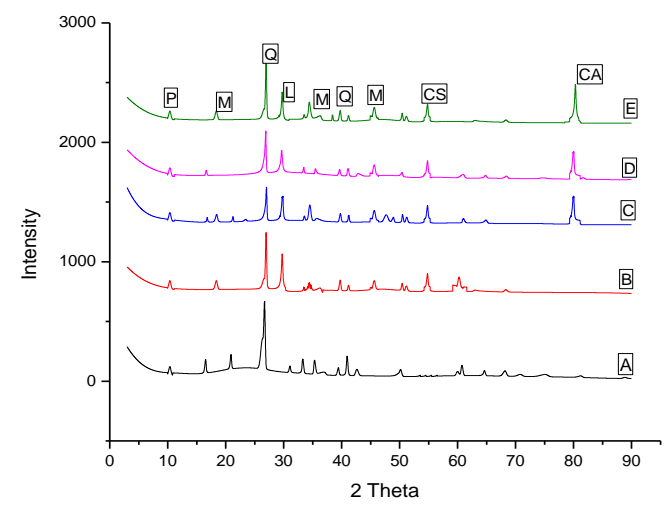

Fig. 8. XRD patterns of DFA (A) and DFA: lime composites (70:30) cured at $80^{\circ} \mathrm{C}$ for $1,2,3$, and 4 days $(\mathrm{B}, \mathrm{C}, \mathrm{D}, \mathrm{E}$ respectively). P: Philipsite K, M: Mullite, Q: Quartz, L: $\mathrm{CaO}, \mathrm{CS}$ : Calcium silicate hydrate, $\mathrm{CA}$ : tri-calcium aluminate hydrate

The major difference between DFA and the DFA: lime composite is the presence of hydration products in the composite. The hydration products are calcium silicate hydrate $(\mathrm{CSH})$ at about $55^{\circ}$ and tri-calcium aluminate hydrate $\left(\mathrm{C}_{3} \mathrm{AH}\right)$ hydrate at about $80^{\circ}$. Though the $\mathrm{CSH}$ peak is normally at $29^{\circ}$ and $50^{\circ}$, the peak at $55^{\circ}$ can also be attributed to $\mathrm{CSH}$ [16]. Basal shift if calcium hydrates at low $\mathrm{Si} / \mathrm{Ca}$ is highly likely due to low silica content in DFA [17]. The presence of tricalcium aluminate has also been reported in low silica FA hydration [18].

One interesting phenomenon is the appearance of $\mathrm{C}_{3} \mathrm{AH}$ only after $48 \mathrm{~h}$ of curing whilst $\mathrm{CSH}$ appears after $24 \mathrm{~h}$ of curing. This is due to the fact that the solubility constant for $\mathrm{CSH}$ is lower than that of $\mathrm{C}_{3} \mathrm{AH}$ [19] and hence $\mathrm{CSH}$ forms faster than $\mathrm{C}_{3} \mathrm{AH}$. There was also a corresponding decrease in the intensity of the lime spectra with increase in curing period as lime is being consumed. The presence of typical DFA phases (Mullite and Quartz) in the composites is further evidence of the presence of DFA which had not gone through hydration. The relative peak intensity of the CSH was $75 \%$ less than that of $\mathrm{C}_{3} \mathrm{AH}$ further proving that $\mathrm{Al}$ was more dominant than $\mathrm{Si}$ in the starting material.

\section{CONCLUSION}

DFA can be stabilised with lime resulting in a composite which can be used for masonry as the 70:30 DFA:lime composite met the minimum requirements for load bearing non exposed masonry and load bearing exposed side construction masonry (ASTM C34-13). The optimum curing temperature was $80{ }^{\circ} \mathrm{C}$ for $96 \mathrm{~h}$. Lime consumption by DFA follows modified Jander Kinetics with an activation energy of $16 \mathrm{~kJ} / \mathrm{mol}$. DFA lime pozzolanic reaction are fast $(69 \%$ lime consumed within $24 \mathrm{~h}$ ) as compared to FA lime reactions. Curing of DFA:lime composites at temperatures higher than $80^{\circ} \mathrm{C}$ result in lowering of late stages strength due to encapsulation of DFA particles with hydration products. The 70:30 composite can be used safely in the environment 
as $75 \%$. The research therefore provides a way to deal with waste from silica leaching of fly ash thereby proving a zero waste process.

\section{Acknowledgements}

The authors would like to thank the University Research Council of the University of Johannesburg for their financial support. The authors are also thankful to the National Research Foundation of South Africa for providing a bursary for the student.

\section{REFERENCES}

1. Petrik, L. Environmental Impact of the Placing of Coal Residue, Fine Coal Residue and Ash in Mined Out Areas Coaltech 2004: pp. 2020-... .

2. Font, O., Querol, X., López-Soler, A., Chimenos, J.M., Fernández, A.I., Burgos, S., Peña, F.G. Ge Extraction from Gasification Fly Ash Fuel 84 2005: pp. $1384-1392$.

3. Gutiérrez, B., Pazos, C., Coca, P. Recovery of Gallium from Coal Fly Ash by A Dual Reactive Extraction Process Waste Management and Research 15 1997: pp. 371-382.

4. Rahaman, R.A., Gafur, M.A., Kurny, A.S.W. Kinetics of Recovery of Alumina from Coal Fly Ash through Fusion with Sodium Hydroxide American Journal of Materials Engineering and Technology 1 2013: pp. 54-58.

5. Hui, K.S., Chao, C.Y.H. Synthesis of MCM-41 From Coal Fly Ash by A Green Approach: Influence of Synthesis pH Journal of Hazardous Materials B 137 2006: pp. $1135-1148$.

6. Dhokte, A.O., Khillare, S.L., Lande, M.K., Arbad, B.R. Synthesis, Characterization of Mesoporous Silica Materials from Waste Coal Fly Ash for The Classical Mannich Reaction Journal of Industrial and Engineering Chemistry 17 2011: pp. $742-746$.

7. Mattias, P., Maura, G., Rinaldi, G. Investigation of Reactions in High-Alumina Fly Ash and Lime Pastes Materials and Structures 22 1989: pp. 287-291.
8. Rao, S.M., Asha, K. Activation of Fly Ash-Lime Reactions: Kinetic Approach Journal of Material Civil Engineering 24 2012: pp. 1110-1117.

9. Biernacki, J.J., Williams, P.J., Stutzman, P.E. Kinetics of Reaction of Calcium Hydroxide and Fly ash ACI Mater J 2001: pp. 340-349.

10. Wang, S. Quantitative Kinetics of Pozzolanic Reactions in Coal/Cofired Biomass Fly Ashes and Calcium Hydroxide (CH) Mortars Construction and Building Materials 51 2014: pp. 364-371.

11. Zhang, Y.M., Sun, W., Yan, H.D. Hydration of HighVolume Fly Ash Cement Pastes Cement and Concrete Composites 22 2000: pp. 445-452.

12. Haha, M.B., De Weerdt, K., Lothenbach, B. Quantification of the Degree of Reaction of Fly Ash Cement and Concrete Research 40 2010: pp. 1620-1629.

13. Nugteren, H.W. Secondary Industrial Minerals from Coal Fly Ash and Aluminium Anodising Waste Solutions. PhD thesis, Delft University of Technology 2011.

14. Cable, M. A Century of Developments in Glassmelting Research Journal of American Ceramic Society 81 1998: pp. $1083-1094$.

15. Chen, C., Gong, W., Lutze, W., Pegg, I.L., Zhai, J. Kinetics of Fly Ash Leaching in Strongly Alkaline Solutions Journal of Material Science 2001 46: pp. 590-597.

16. Elena. J., Lucia, M.D. Application of X Ray Diffraction (Xrd) And Scanning Electron Microscopy (Sem) Methods to The Portland Cement Hydration Processes Journal of applied Engineering Sciences 2 2012: pp. 35-42.

17. Grangeon, S., Claret, F., Linardb, Y., Chiabergea, C. Xray Diffraction: A Powerful Tool to Probe and Understand The Structure of Nanocrystalline Calcium Silicate Hydrates Acta Crystallographica Section B Structural Science Crystal Engineering and Materials B 69 2013: pp. 465-473.

18. Verhasselt, A. Characterization of the Pozzolanicity of FlyAsh in Proceedings of 7th International Symposium on the Chemistry of Cement 3 1980: pp. 116-121.

19. Lothenbach, B. Thermodynamic Equilibrium Calculations in Cementitious Systems Materials and Structures 43 2010: pp. $1413-1433$. 